\title{
Innovation of Internet Finance and Small and Micro Enterprise Financing Mode
}

\author{
Qiufeng $\operatorname{Pan}^{1}$ \\ ${ }^{1}$ Nanchang Business College Of Jxau, Ganzhou, Jiangxi, 332020, China
}

\begin{abstract}
With the rapid development of the Internet, Internet financial services are also constantly popularizing, constantly occupying an important position in the financial market, the rapid development of Internet finance has improved the way of social financial services, enriched the types of financial products, effectively solved the problems of small and micro enterprises in financing difficulties, high financing costs, slow financing speed, and played an important role in the financing of small and micro enterprises. But under the development mode of Internet finance, the financing mode of small and micro enterprises still faces some shortcomings and problems. The purpose of this paper is to introduce the current situation of Internet finance and small and micro enterprise financing, take this as the starting point to study, further analyze the problems and reasons, and analyze the relevant countermeasures according to the problems.
\end{abstract}

\section{Introduction}

Driven by today's social and economic development and the development of science and technology, the Internet has had an abyss of influence in all walks of life, affecting not only people's work and life, but also the development of various industries. Small and micro enterprises are the main body and foundation of China's national economic development and social and economic progress, and are an important guarantee for the strong country and the rich people. For the social and economic development, it plays a great role in increasing tax revenue, improving people's livelihood, increasing employment, perfecting the structure of market economy and ensuring economic stability. Small and micro enterprises are actually the general names of micro enterprises, small enterprises, family small enterprises and other enterprises. All along, small and micro enterprises play an important role in the economic structure and economic development of our country.

\section{Financing Of Small And Micro Enterprises}

China has a large number of small and micro enterprises, design a large number of production areas, mainly concentrated in catering services, wholesale sales and other tertiary industries, with a large number of enterprises, small scale, involving a wide range of characteristics, which leads to small and micro enterprises in the strategic layout has great development limitations, mainly rely on cheap labor low-cost operation, lack of a large amount of capital support.
Moreover, small and micro enterprises are relatively backward in management methods, especially in corporate culture and enterprise system. Managers of small and micro enterprises often lack professional management knowledge and level, lack of financial management system at night, relatively poor ability to prevent and defuse social risks, sensitive to policy changes and economic changes.

In the past, when small and micro enterprises have capital constraints, they will go to banks and other financial institutions to apply for loans, and the national team of small and micro enterprises loans are also increasing year by year, but small and micro enterprises still encounter many problems in financing can not be effectively solved. Some banks have a high threshold for financial loans, which makes many small and micro enterprises unable to meet the loan conditions, so they can not borrow money, or some small and micro enterprises meet the loan conditions, but the approval process is slow and the amount issued is low. Traditional bank lending, the first consideration is the security of funds, banks issued loans to small and micro enterprises, because small and micro enterprises are small, relatively low economic benefits, banks worry that the loans released can not be recovered, and the return on loans is also low. This results in many small and micro enterprises unable to obtain loans through effective channels, increasing the financing costs of small and micro enterprises.

\section{The Development Connotation Of Internet Finance}

Internet finance, as a technical product of the development of science and technology, is a new type of

\footnotetext{
*Corresponding author's e-mail: 739960103@qq.com
} 
financial service which combines traditional finance and Internet technology. To improve the structure of financial products and achieve the rapid development of financial services. Internet finance has the characteristics of convenience and quickness in use. Internet finance, through the information network, is not limited by regional time. It is convenient for small and micro enterprises to apply for loans anywhere and at any time through the network platform. The loan procedure is simpler and more convenient than the traditional offline loan approval, which can maximize the financing requirements of small and micro enterprises. At the same time, with the development of inclusive finance, the main service object of Internet finance is small and micro enterprises, and Internet credit institutions analyze the assets and operation of small and micro enterprises through big data, These data can be shared with other Internet financial service institutions, and the credit scoring standard and evaluation system of network credit can be established and perfected to achieve the recycling of loan data and improve the loan efficiency.

With the development of the network, the Internet has brought great convenience to people's life, but in the field of Internet finance, it still needs long-term construction and planning. In the process of development, Internet financial services should constantly break through and surpass, strengthen the ability of scientific and technological innovation and maintain the scientific and technological security of Internet financial services. At the same time, because the Internet financial service is a new thing, it is not perfect in various laws and regulations, especially the legal system related to financing, and there are still defects in management. Therefore, it is necessary to speed up the construction of the Internet rule of law system, ensure the people and small and micro enterprises to carry out safe financing on Internet financial services projects, continuously improve the Internet financial planning system and level, establish comprehensive and systematic development goals, fully solve the financing difficulties and slow financing problems of small and micro enterprises, so as to promote economic development.

\section{Problems Related To Internet Finance Financing For Small And Micro Enterprises}

\subsection{Credit Risk Problem}

Because of the characteristics of the Internet, there are some risks in the financing mode of Internet finance, and there is a lack of certain financing security. Although the development of Internet finance has made great progress and development space, in the process of Internet financial financing, the credit evaluation system of small and micro enterprises has not been fully established, and the credit assessment data are not provided completely.

\subsection{Enterprise data issues}

With the continuous development of the Internet financial industry, many small and micro enterprises have been brought fast and convenient, but at the same time, there are many disadvantages, such as the lack of comprehensive and limited data collection and analysis of small and micro enterprises, the current people's Bank of China financial institutions database information, the Internet platform information collection is not completely accurate, it is necessary to establish a more complete and large database, which requires a lot of time, money and manpower, can not be effectively established in a short time, can not obtain accurate data related to small and micro-enterprise trade transactions.

\subsection{Network regulatory issues}

At present, due to the rapid development of Internet technology in China, the development of Internet financial services has also been rapidly developed, but there are still some problems in the network supervision of Internet finance in the relevant functional departments. This is mainly reflected in the fact that the relevant laws, regulations and departmental regulations have not issued a set of systematic network financing supervision laws and regulations, and there are not many policies and regulations to prevent and resolve the possible risks and problems in the process of network financing, which can easily lead to some illegal situations in the process of network financing, resulting in the loan of credit institutions can not be recovered, In the development of Internet financial services, network financing has to bear the corresponding market risk problem because it is not bound by space and time.

\section{Innovation And Development Of Financing Mode Of Small And Micro Enterprises Under Internet Finance.}

Internet finance provides financing for small and micro enterprises in the following ways: 


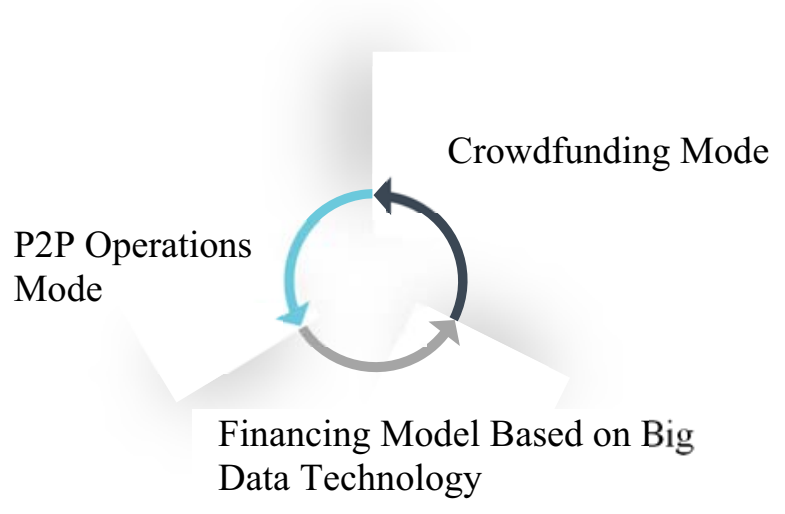

Figure1. Internet Finance For Small And Micro Enterprises To Provide FinAnCing Model

In order to innovate and develop the financing mode in Internet finance, small and micro enterprises must insist on:

\subsection{Continuous optimization of Internet financing environment}

In order to ensure the smooth access of small and micro enterprises to financing under Internet finance and promote the benign and stable development of Internet finance, it is necessary to improve the financing environment of the Internet. Internet financial service institutions should not only rely on big data information base to analyze problems and risks, but also establish and improve the sharing mechanism of all kinds of network information data, break the problem of independent access to information data by major information databases, strengthen the communication and exchange of Internet financial institutions, build a standardized and unified credit system evaluation system, optimize the credit evaluation environment of small and micro enterprises, and strengthen the information communication between small and micro enterprises and network financial institutions, Improve and develop the transparency of credit information of small and micro enterprises, prevent and resolve the credit risks of small and micro enterprises, and meet the loan needs of small and micro enterprises.

\subsection{Strengthening network financial management}

With the development of the times, our country must strengthen the control of the related risks when dealing with the related problems of Internet finance, introduce some relevant policies and regulations to strengthen the current supervision in the field of Internet finance, ensure the healthy and rapid development of Internet finance, grasp the entry of Internet financial service institutions, and prevent the risk of loans to Internet finance and small and micro enterprises. To establish and improve the relevant provisions of the laws and regulations of the Internet financial service system, to increase the security of Internet finance, and to ensure the smooth financing activities of small and micro enterprises in Internet financial institutions.

\subsection{Changing traditional financing patterns}

In the process of development, small and micro enterprises should make full use of the development opportunities of network finance, and transform the diversified financing characteristics of Internet finance into their own financing strength. Small and micro enterprises should actively formulate their future development direction, adjust their own financing methods in time, and make a scientific judgment on the future development trend of market economy and the development needs of society in combination with their own development characteristics and actual conditions.

\subsection{Strengthening self-construction of small and micro enterprises}

The rapid development of Internet finance has added impetus to the development of small and micro enterprises. In order to obtain financing smoothly in Internet finance, small and micro enterprises must make great efforts to improve their comprehensive strength and enhance their reputation. Improve the internal control system of enterprises. Small and micro enterprises have been in a passive situation in the market competition because of their own weak foundation, weak strength and poor ability to resist risks. In the process of Internet financial credit, the vast number of small and micro enterprises must strengthen their own construction, constantly improve their soft and hard power, establish and improve various financial management systems and daily management systems. If there are problems in their own financial situation as an enterprise, there will be adverse data information in the Internet financial data information base, which will have adverse consequences for small and micro network financing. Therefore, small and micro enterprises should establish and improve all kinds of management systems, enhance the influence of enterprises, and enhance the good image of enterprises. In addition, our country provides a safe and stable development platform and development environment for small and micro enterprises by increasing the support for small and micro enterprises. Small and micro enterprises 
themselves must strengthen the management of internal work, improve the market competitiveness of small and micro enterprises, enhance their social credit, and strengthen the ability of small and micro enterprises to deal with all kinds of risks in the market.

\subsection{Strengthening the Training of Internet Financial Talents}

As a science and technology, the development of the Internet can not be separated from the innovation of scientific and technological talents. Similarly, the development of Internet finance can not be separated from the participation of a large number of financial talents. Under this background, small and micro enterprises should pay more attention to the cultivation and introduction of network financial talents. Talent, as a unique resource of social scarcity, has become an important part of enterprise development. Only with strong talents in relevant financial fields and financial innovation thinking, can small and micro enterprises in the process of Internet financial financing and react more quickly to the change and development of the market, The vast number of small and micro enterprises must increase the training of relevant talents in the Internet financial industry in order to better finance and bring strong impetus to the future development.

\section{CONCLUSION}

Under the background of the Internet era, small and micro enterprises should constantly adapt to the development of the times in the tide of the times, constantly improve their own, strengthen their own construction through the opportunity of Internet financial development, and innovate financing methods.

\section{REFERENCES}

1. Wang,J.H.(2019)Innovative thinking of Internet finance and financing mode of small and micro enterprises $[\mathrm{J}]$.Accounting for township enterprises in China.

2. Liang,Y.Wang,L.(2019)Research on the Innovation of Small and Medium-sized Enterprises of Internet Finance[J].Modern Marketing (Business Edition).

3. Wang,S.H.(2015)Research on Financing Mode of Small and Micro Enterprises in Internet Finance[D].University of Foreign Trade.

4. Qian,Y.J.(2020)Research on the Innovation and Risk Management of the Financing Mode of Small and Micro Enterprises in the Context of Internet Finance[J].Modern Marketing (forthcoming).

5. Liu,Y.M.(2020)Research on Multi-financing Mode of Small and Micro Enterprises Based on Internet Financial Background[J].Enterprise reform and management. 